\title{
CONSTITUTIONAL PRINCIPLES OF TAXATION: DOCTRINAL APPROACHES TO TYPOLOGY
}

\author{
Halyna Rossikhina' \\ V.N. Karazin Kharkiv National University, Ukraine \\ Mikhailo Hultai ${ }^{2}$, Inna Shrub ${ }^{3}$ \\ National Academy of Internal Affairs, Ukraine
}

\begin{abstract}
The aim of the article is the study of theoretical and methodological, and doctrinal approaches to the typology of the constitutional principles of taxation and, on this basis, a definition of ways to improve domestic legislation in this sphere. The subject of the study is the constitutional principles of taxation. Methodology. The research is based on general scientific and special-scientific methods and techniques of scientific knowledge. The historical and legal method enabled to determine the preconditions for the origin of taxes as the main source of filling the state budget revenues in Ukraine and in the world, as well as the formation of scientific and theoretical views on the nature, problems and methods of taxation. The comparative legal method was used to compare doctrinal approaches to the differentiation of tax principles. The systematic and structural method contributed to the recognition of the tax system as a special institutional and functional form of tax relations. The methods of grouping and classification formed the basis of the original approach to the differentiation of constitutional principles of taxation by the most important and significant in practice criteria. The formal and legal method enabled to investigate thoroughly the state of legal regulation of the domestic taxation system, to identify its shortcomings, gaps, contradictions and miscalculations, as well as to develop recommendations aimed at their elimination. The results of the study revealed that the constitutional principles of taxation should be regarded as synthesizing principles, unifying links, the realistic basis for the origin, formation, and functioning of relations arising in the collection of taxes and fees. They define law-making, law-executing, and law-enforcement activities, coordinate the functioning of financial and legal regulation. Practical implications. In the research, firstly, the key aspects of the genesis of the constitutional principles of taxation are outlined; secondly, scientific approaches to their classification are analysed and compared with existing ones in the special literature; thirdly, the original opinion on their differentiation is substantiated. Relevance/originality. The proposed original approach to the differentiation of the constitutional principles of taxation is the basis for improving the most promising directions of development of domestic legislation in this area.
\end{abstract}

Key words: taxes, principles, principles of taxation, constitutional principles of taxation, types of constitutional principles of taxation.

JEL Classification: H23, D01, H21

\section{Problem statement}

For the reason that the financial system includes relations regarding the accumulation and use of the state's financial resources, it requires the improvement of its most important components related to the formation of the budget and extra-budgetary funds. The issue of legal regulation of taxation remains significant because the main source of revenue generation in Ukraine is taxes. Therefore, at the present stage, tax transformations are important in the development of market relations. In view of this, the transformation of the Ukrainian tax system, financial and legal regulation of taxes and fees is of key importance. An efficient tax system is an integral part of any modern state. Taxes are not only the main source of budget revenues but also a powerful means of public balance, a guarantor of social protection of citizens and formation of a modern material basis of state and local self-government sovereignty (Bekh, 2001).

\footnotetext{
Corresponding author:

${ }^{1}$ Department of Law Faculty, V.N. Karazin Kharkiv National University.

${ }^{2}$ Department of Constitutional Law and Human Rights, National Academy of Internal Affairs.

${ }^{3}$ Department of Administrative Activity, National Academy of Internal Affairs.

E-mail:innashrub@gmail.com
} 


\section{Literature review}

In legal science, the nature of constitutional principles was developed by domestic and foreign scientists such as N.V. Zaiats, B.V. Kalynovskyi, V.V. Kravchenko, A.M. Kolodii, V.F. Pohorilko, O.V. Sovhyria, V.L. Fedorenko, O.F. Frytskyi, and others. In their scientific works, A.I. Berlach, Ya.V. Hretsa, V.V. Kostytskyi, M.P. Kucheryavenko, A.M. Novytskyi, N.Yu. Pryshva, O.B. Chornomaz and others study the essence and types of the principles of tax law. However, the issue of constitutional principles of taxation is not considered enough, which, in turn, indicates the relevance and importance of the chosen topic of the scientific article. The aims of the article. Consequently, it is relevant to consider the doctrinal approaches to the typology of the constitutional principles of taxation that constitutes the aim of the article. To implement it successfully, the following tasks should be resolved: firstly, to outline the key aspects of the genesis of the constitutional principles of taxation; secondly, to analyse existing scientific approaches to the types of the taxation principles in the specialized literature; thirdly, the original opinion on their differentiation is substantiated.

\section{The main material}

Taxes are the main source of revenue for the budget, that is, they perform a fiscal function. They are conditioned by the emergence of the state and formation of a material component of its functioning. The wider the powers of the state, the more important taxes, fees, and mandatory payments. Thus, one of the constitutional duties of a citizen is the obligation to pay taxes and fees in the procedure and amount established by law (Konstytutsiia Ukrainy), while tax legal capacity of Ukraine arises from the very origin. Any tax, levied in the country, is compulsory and supposed to take away a part of the funds of individuals and legal entities. That is, paying taxes are viewed negatively by citizens, besides high rates of some taxes lead to the indignation of certain segments of the population.

It should be noted that the origin of taxes usually refers to the period of formation of the first states. A state and its institutions needed to be kept, and the population was forced to choose whether to feed soldiers and officials of their ruler or to feed conquerors. Up to the seventeenth century, tax systems were disorganized and poorly developed. Later, states of Europe contributed to the development of an ideology aimed at developing the theoretical foundations of taxation. For example, A. Smith in An Inquiry into the Nature and Causes of the Wealth of Nations formulates for the first time the principles of taxation (only four), defines tax payments, their place in the financial system of the state, and emphasizes that taxes for a payer are an indicator of freedom, not slavery. In the nineteenth century, scientific and theoretical views on the nature, problems, and methods of taxation, compliance with the legal form of their introduction and collection were formed. In other words, various strata of the population realized the general (public) interest in the necessity of paying taxes, as well as the legal regulation of taxation relations because of understanding the state's interest in fiscal coverage of the budget revenues (Rossikhina). Therefore, on the one hand, the constitutional regulation of taxes and duties constructs the material basis for ensuring the effectiveness of the state functioning, and on the other, prevents state tyranny. This approach is embodied above all in the constitutional principles of taxation.

According to V.F. Pohorilko, the principles of the constitutional law of Ukraine are the guiding principles, ideas that determine the essence, content, directions, and forms of constitutional and legal regulation (Pohorilko, 2008). In turn, G.A. Gadzhiev emphasizes that constitutional principles are the guiding principles that express the essence of the legal system, constitute its content and possess the highest legal imperative (Gadzhiev, 2006). O.V. Demin argues that the basic essence of any principle, including a constitutional group, is in establishing the legal basis of a special group of norms remaining independent from them in the contest (Demin, 1998). According to A.O. Khrabrov, the principles of law are its supporting structures, a bridgehead for understanding norms, institutions, branches, and the whole system of law, which are a clear benchmark for law-making, law-executing, and law-enforcement activities of the state (Khrabrov, 2012). V.I. Gureev argues that constitutional principles form the basis of legal regulation of the tax system in general and the whole value chain in tax law. From this perspective, it should be emphasized that the vital system of guarantees and qualities inherent in the tax system of any legal, democratic and social state is determined precisely by the constitutional principles of tax policy (Gureev, 1997).

According to Paragraph 4.1 of the Decision of the Constitutional Court of Ukraine on the compliance of the Constitution of Ukraine (constitutionality) with the provisions of Article 69 of the Criminal Code of Ukraine (case on imposition of a more lenient punishment by the court) No. 15-rp / 2004 of November 2, 2004, the rule of law is domination of law in society. The rule of law requires that the state implements it in law-making and law-enforcement activities, in particular, in laws, which, by their content, must be permeated with ideas of social justice, freedom, equality, etc. The rule of law is manifested in the law, which is not limited only by the legislation as one of its forms but also includes other social regulators, such as norms of morality, traditions, customs, etc., legitimized by society and conditioned by the historically achieved cultural level of society. All these elements of the law are united by a quality that corresponds to the ideology of justice, the idea of law, 
which has largely been reflected in the Constitution of Ukraine (Rishennia Konstytutsiinoho Sudu Ukrainy).

As noted above, A. Smith was first to develop and argue the well-known four principles that should be implemented in the tax system of any modern state, namely: the certainty of taxes (the rate, terms and procedure of payment), convenience (favourable conditions for the taxpayer), equity (payers must pay an equal share of their income), as well as efficiency (the use of efficient and cheap tax administration measures).

The majority of modern states apply these principles in tax policy. However, nowadays scientists review the doctrinal list of the principles of taxation. For example, M. P. Kucheriavenko differentiates the following types of groups of principles of legal regulation: the principles of taxation, the principles of tax law, the principles of the tax system, the tax principles, the principles of tax legislation (Bekh, Dmytryk, Kobylnik, 2003). T.M. Zatulina adds to the constitutional principles of regulating tax relations the following: the rule of law and legality; the principle of publicity and social orientation; the principle of universality and equality; the principle of state protection of the payer; the principle of tax system development in compliance with on the form of government; the principle of tax autonomy of local self-government (Zatulina, 2008). According to A.O. Khrabrov, in taxation regulations, the principles, provided for in the Constitution, should be detailed, as well as the list of general and specific principles of tax law, their legal content and classification should be recognized by the legislation (Khrabrov, 2012). Moreover, A.V. Bryzgalin emphasizes the need to differentiate all principles of taxation by economic, legal, and organizational (Bernik, Bryzgalin, Golovkin et al., 1997). O.V. Demin divides the principles of taxation into general (for example, publicity, the unity of the tax system, equity, single taxation, etc.) and special (Demin, 1998). In addition, foreign legal literature proposes other approaches to the classification of tax principles with three separate groups, each of which includes a certain set of mechanisms for the implementation of significant constitutional and legal institutions in taxation, namely: a) principles that ensure the implementation and observance of the foundations of the constitutional system; b) principles that ensure the implementation and observance of the fundamental rights and freedoms of taxpayers; c) principles that ensure the implementation and observance of the doctrines of federalism.

Therefore, there are quite different classifications of the constitutional principles of taxation, each of which reveals the main aspects of financial and tax policy uniquely. Analysing financial and legal regulation, it should be noted that the basic principles of financial and legal regulation are general principles of legal regulation, such as: 1 ) objectivity (the effectiveness of financial and legal regulation depends on consistency of the rules of financial law with the laws of social and economic development); 2) democracy, humanism, professionalism; 3) scientific character; 4) the unity of equal rights and equal responsibilities; 5) reasonability (provides the right financial and legal qualification, choice of a relevant norm and its dissemination to assessing the behaviour of the addressee of the enforcement of law); 6) legality (the need to adhere strictly to the requirements of the financial and legal norm by all participants in the financial legal relationship, the established by law procedure for the application of these norms, the provision of strict liability for violations of legal requirements, financial discipline; legislative regulation of the most important relations in financial activity; technical excellence of acts, etc.) (Rossikhina).

However, L.V. Melekh emphasizes that, by following the principle of legality, the state strives for a clear and steady implementation of the existing legal norms using various methods and means, including state coercion. As a result, the legality is not only a principle, but also a method of activity of not only state bodies and their officials, but also other participants in social relations (Melekh, 2009).

The general theory of law puts forward general requirements (principles of law enforcement) to all stages oflaw enforcement activities, such as reasonability, expediency, and justice of enforcement, ensuring its legality. It should be emphasized that the principle of legality is fundamental to the implementation of the rules of financial law. In the context of this, P.M. Rabinovich notes the lawful guarantees of legality, such as: 1) rules of law, precisely aimed at the maintenance and protection of the law; 2) activities of certain entities regarding the enforcement of these norms; 3 ) enforcement acts (documents that record the results of these activities) (Rabynovich, 1979). The principle of legality is key because it requires the steadily and strict financial law compliance by all addressees. In addition, it provides for a compliance with all procedural requirements in qualifying the circumstances of the case, the choice and application of rules of law. Moreover, overcoming the consequences of the global financial crisis, arrangement of a stable financial and economic existence of the state lead to growing influence and authority of financial ( $\operatorname{tax}$ ) laws, their strict compliance and implementation by all subjects of relations in financial activity of the state. All these circumstances contribute to the enhancement of legality in the financial and tax area, obligatory financial ( $\operatorname{tax}$ ) discipline, strict implementation of the rule of law in financial and tax law (Kucheriavenko, Bilinskyi, Holovashevych et al., 2010).

According to P.O. Nedbailo, the principle of legality in the relations of state bodies with the population is combined with the proper competence of the state bodies and their officials, as well as with the clarity and certainty of the rights and obligations of citizens. Under the rule of law, the rights and freedoms of a citizen 
are steady and inviolable. The principle of legality is the basis of compliance with all procedural aspects in qualifying the circumstances of the case, choice, and use of law (Nedbailo, 1960).

Implemented and reflected in the acts of law, the principle of equity means that the decision does not contradict to the needs and interests of enterprises, institutions, and corresponds to the moral traditions of both society as a whole and individual citizens in particular. This principle is a philosophical category, a certain criterion. That is why in judging any offense, its causes, as well as the personality of the offender should be considered. According to R. Tsyppelius, the right should regulate human behaviour to distribute fairly the benefits (values, advantages) and burdens (costs, liabilities); to satisfy conflicting interests in accordance with their weight and significance; to punish offenders adequately, in other words, to resolve the conflicts that arise in society justly (Tsyppelius, 2004).

The principle of expediency involves evaluating specific law enforcement on certain grounds. For example, whether the application of the law is needed at all and what individual characteristics should be considered by the subject of enforcement. The principle of reasonability ensures proper qualification, choice of a relevant norm and its dissemination to assessing the behaviour of the addressee of the enforcement of the law. Other principles are also applied considering the principle of democracy, which is the basis for all activities of state and public organizations in Ukraine.

From the perspective of this scientific research, the principles of taxation are interdependent and interconnected, each of them is polysemic, selfcontained, complex, and each encompasses several constitutional and legal institutions. Thus, the constitutional principles of taxation include:

1. The principle of territorial conditionality, which reveals the essence of decentralization within taxation of a unitary state. Decentralization contributes to financial independence and budget autonomy of local budgets, provides an opportunity to regulate taxation of territorial communities independently, without the interference of central bodies in the activities of local self-government bodies in resolving issues that fall within their competence. Articles 7, 140, 142 of the Constitution of Ukraine as of June 28, 1996, provide for that local self-government, the material and financial basis of which is both community property and local budget revenues, including income from local taxes and fees, is recognized and guaranteed in Ukraine. In addition, in the whole state, uniform bases of taxation are established providing an opportunity to balance all rights and obligations of the subjects of financial and economic relations, as well as national taxes (Konstytutsiia Ukrainy). According to Paragraph 4.4 of Article 4 of the Tax Code of Ukraine on December 2,
2010, the establishment and abolition of taxes and duties, as well as privileges of their payers, are carried out consistent with the norms of this Code by the Verkhovna Rada of Ukraine, as well as the Verkhovna Rada of the Autonomous Republic of Crimea, rural, rural settlement, city councils within the limits of their authorities, defined by the Constitution of Ukraine and laws of Ukraine. An important characteristic of the degree of decentralization in the country is the ratio of tax powers of the centre and regional budgets. Financial decentralization enables the long-awaited freedom of the regions, as well as profit on their own (revenues from certain taxes are directed to local budgets, as well as local councils have the right to set rates and provide privileges) (Podatkovyi kodeks Ukrainy).

2. The principle of equity means that taxpayers are obliged to pay taxes and fees according to their real incomes. In general, the principle of recognizing the true citizen-taxpayer's ability to pay when collecting taxes and fees should be used. Paragraph 4.1.6 of Article 4 of the Tax Code of Ukraine states clearly and fairly that social equity in tax relations is the establishment of taxes and fees in accordance with taxpayers' ability to pay. This principle is supported by the principle of equality, disclosed in the current tax law. Article 4 of the Tax Code of Ukraine provides for that equality of all payers before the law, prevention of any manifestations of tax discrimination ensure the same approach to all taxpayers, regardless of social, racial, national, religious affiliation, form of ownership of a legal entity, citizenship of an individual, place the origin of capital (Podatkovyi kodeks Ukrainy).

3. The principle of legality implements the general concept of the division of power. Part 2 of Article 92 of the Constitution of Ukraine stipulates that the system of taxation, taxes and fees are based on laws exclusively (Konstytutsiia Ukrainy). In addition, Paragraph 4.2 of Article 4 of the Tax Code of Ukraine provides for that national, local taxes and fees, the collection of which is not provided for by this Code, shall not be subject to payment. In addition, Paragraph 7.3 of Article 7 of the Tax Code of Ukraine emphasizes that any taxation issues are regulated by this Code and cannot be established or amended by other laws of Ukraine, except for laws that contain exclusively provisions for amendments to this Code and/or provisions establishing liability for violations of norms tax legislation (Podatkovyi kodeks Ukrainy).

4. The principle of the public purpose of establishing and collecting taxes and fees. According to the Basic Law in force, Ukraine is a sovereign and independent, democratic, social, and legal state. This principle involves the interaction of public (state) interests and private legal interests of taxpayers, based on real incomes. It is aimed at realizing the very social essence of the state, which should be oriented towards ensuring a decent life of people. 


\section{Conclusions}

Therefore, the constitutional principles of taxation are synthesizing principles, unifying links, the realistic basis for the origin, formation, and functioning of relations arising in the collection of taxes and fees. They define lawmaking, law-executing, and law-enforcement activities, coordinate the functioning of financial and legal regulation.
The principles of constitutional taxation include the principle of territorial conditionality, the principle of equity, the principle of legality, the principle of the public purpose of establishing and collecting taxes and fees. The proposed list of principles of constitutional taxation enables to balance the constitutional values of a democratic, social, and legal state within the framework of tax legal relations.

\section{References:}

Bekh H.V. (2001). Pravove rehuliuvannia nepriamykh podatkiv v Ukraini [Legal Regulation of Indirect Taxes in Ukraine] (Dissertation of $\mathrm{PhD}$ in specialty 12.00.07). Kharkiv, 207 p. (in Ukrainian)

Konstytutsiia Ukrainy [The Constitution of Ukraine]. No. 254k / 96-VR of 28 June 1996. Retrieved from: http://zakon5.rada.gov.ua/laws/ show/254к/96-вp (in Ukrainian)

Rossikhina H.V. Rol finansovo-pravovykh norm u mekhanizmi finansovo-pravovoho rehuliuvannia [The role of financial and legal norms in the mechanism of financial and legal regulation]. Retrieved from: http://www.pravoznavec.com.ua/period/article/2849/\%C3\#chapter (in Ukrainian)

Pohorilko P.F. (2008). Konstitutsiine pravo Ukrainy: Navchalnyi posibnyk [Constitutional Law of Ukraine: A teaching manual]. K.: Yurydychna Dumka, 308 p. (in Ukrainian)

Gadzhiev G.A. (2006). Konstitutsionnye osnovy sovremennogo prava sobstvennosti [Constitutional bases of modern property right]. Zhurnal rossiyskogo prava [Journal of Russian Law], 12, 30-41. (in Russian)

Demin A.V. (1998). Obshchie printsipy nalogooblozheniia (analiz sudebno-arbitrazhnoi praktiki) [General principles of taxation (analysis of forensic arbitration practice)]. Khoziaistvo i pravo [Economics and law], 2, 95-100. (in Russian)

Khrabrov A.O. (2012). Konstytutsiini normy-pryntsypy yak zahalnopravovi pryntsypy podatkovoho prava [Constitutional norms-principles as general legal principles of tax law]. Uchenye zapysky Tavrycheskoho natsyonalnoho unyversyteta im. V.I. Vernandskoho. Seryia «Yurydycheskie nauki $»$ [Scientific notes of V.I. Vernandskii Tavrycheskii National University]. (Vol. 25 (64)), 1, 129-133. (in Ukrainian)

Gureev V.I. (1997). Rossiiskoe nalohovoe pravo: ucheb [Russian tax law: A teaching manual]. M.: Ekonomika, $383 \mathrm{p}$.

Rishennia Konstytutsiinoho Sudu Ukrainy: v 3 t. [Decision of the Constitutional Court of Ukraine: in 3 volumes]. (2010). (Vol. 1). S.A. Kuzmin (Ed.). K.: PALIVODA A.V, 496 p. (in Ukrainian)

Bekh H.V., Dmytryk O.O., Kobylnik D.A. (2003). Podatkove pravo: Navchalnyi posibnyk [Tax law: A teaching manual]. M.P. Kucheriavenko (Ed.). K.: Yurinkom Inter, 400 p. (in Ukrainian)

Zatulina T.M. (2008). Konstitutsionno-pravovye osnovy regulirovaniia nalogovykh otnoshenii v Rossiiskoi Federatsii [Constitutional and legal bases of regulation of tax relations in the Russian Federation] (Dissertation Abstract of PhD in specialty 12.00.02 Constitutional Law; Municipal law). Moscow, 21 p. (in Russian)

Bernik V.R., Bryzgalin A.V., Golovkin A.N., et al. (1997). Nalogi i nalogovoye pravo: ucheb. posob. [Taxes and tax law: A teaching manual] A.V. Bryzgalin (Ed.). M.: Analitika-Press, 608 p. (in Russian)

Melekh L.V. (2009). Zakonnist u pravozastosovnii diialnosti [Lawfulness in law-enforcement activity] (Dissertation of PhD in specialty 25.00.01). L., 185 p. (in Ukrainian)

Rabynovich P.M. (1979). Problemy teorii zakonnosty razvitoho sotsializma [Problems of the theory of the legality of developed socialism]. L.: Publishing House of the Lviv University, 203 p. (in Russian)

Kucheriavenko M.P., Bilinskyi D.O., Holovashevych O.O. et al. (2010). Aktualni pytannia nauky finansovoho prava: [Topical issues of financial law science] (Monograph). M. P. Kucheriavenko (Ed.). Kh.: Pravo, 464 p. (in Ukrainian)

Nedbailo P.E. (1960). Primenenie sovetskykh pravovykh norm [The Application of Soviet Legal Standards]. M.: State-Publishing House of Juridical Literature, 512 p. (in Russian)

Tsyppelius R. (2004). Yurydychna metodolohiia [Legal methodology]. Translated, adopted and applied of Ukrainian law). K.: Referat, 176 p. (in Ukrainian)

Podatkovyi kodeks Ukrainy [The Tax Code of Ukraine]. No. 2755-VI of December 2, 2010. Retrieved from: http://zakon3.rada.gov.ua/laws/show/2755-17 